\title{
A képesfák, szentfák szóhagyománya: faképnél hagy
}

A faképnél hagy (valakit) szólást ma is használjuk. Jelentése a szólástárban: a) váratlanul, egy szó vagy búcsúzás nélkül távozva otthagy valakit; b) hirtelen messze megelöz valakit (Bárdosi 2003: 86). Gyakran alkalmazott szólásról van szó, mutatja néhány frissebb adat:

(1) Faképnél hagy a fapados: 15 utasa nélkül szállt fel a gép (Bama.hu1).

(2) Faképnél hagy, szó nélkül lelép. Ök azok a csillagjegyek, akik váratlanul elhagynak (Égi Jelek, Facebook-fórum²².

Ezenkívül tele van az internet a faképnél hagy szólásnak a szakirodalomból származó félresiklott magyarázatának az ismételgetésével. Például egy, a középiskolásoknak szóló portál bejegyzése:

(3) Faképnél hagy. Jelentése, hogy valaki ott hagy valakit szó nélkül és elmegy. Ez onnan ered, hogy a házakat nagy kapuk díszítették. Még ma is megtalálhatóak egyes házaknál, különösképpen igaz ez Erdélyre. A kapukon pedig általában volt egy kép, esetleg egy ábra. A szokás szerint a házigazda mindig kikísérte a vendéget. Beszélgettek egy kicsit, majd a vendég elment, a házigazda viszont ott maradt. Vagyis a kapunál, amin a fakép van. Nem volt neki negatív jelentése, ezt már az utókor értelmezte így (Középsuli.hu³).

De miért téves ez a bizonytalan múltba vezető magyarázat? És egyáltalán mi az a fakép? Annyit rögtön megállapíthatunk, olyan szó (nyelvi reliktum), amely önmagában nem használatos, csak ebben az egy szólásban él (korábban több szólásbeli változata is volt).

Mai szólásmagyarázó szótáraink előszeretettel állítják a faképről, hogy a jelentése 'faszobor, fabálvány', sőt: 'kapufa, kapubálvány'. Például Szemerkényi Ágnes szólásszótárában: „A szólásokban szereplő fakép... olyan faszobrot, vagy fabálványt (jelent), amelytől hajdan elbúcsúztak a házból kijövő emberek.” Akinek ennyi nem elég, az kap egy kis misztikus magyarázatot is: „Ez a kapufélfa, vagy kapubálvány... sokszor egy faragott emberformájú alak volt” (Szemerkényi 2009: 393). Ugyanez szerepel Bárdosi Vilmosnál is (2015: 152): „Itt a fakép már nem akármilyen faszobrot, fabálványt jelentett, hanem olyasvalamit, amitöl a házból kifelé jövet el szoktak búcsúzni. Ez pedig a kapufélfa, a kapubálvány lehetett [...]. Ezek a kapubálványok, faképek az ősi hitvilág emlékeiként régen a házat és annak lakóit védelmező szellemeket ábrázolták."

1 https://www.bama.hu/orszag-vilag/fakepnel-hagy-a-fapados-15-utast-hagyott-itthon-egybudapesti-jarat-1428627/

2 https://www.facebook.com/797223323799368/posts/1061619900693041/

3 https://kozepsuli.hu/honnan-erednek-szolasokkozmondasok/ 
A legkorábbi történeti adatokban azonban nem találkozunk kapubálvánnyal. Pesti Gábor 1536-ban megjelent Aesopus-átdolgozásában szerepel:

(4) Az emberről és fa képről. Egy néminemí embernek vala házába egy fa képe, mellyet isten gyanánt imád vala, és könyereg vala neki, hogy valami jót tenne vele. De míg inkább imádkozik vala neki, annál inkább napról napra el szegényil vala. Végre meg búsula, az lábát kapá neki, és kezdé úgy az falhoz verni fejét, mely mikoron meg törött volna, nagy sok aran forint hulla ki belőle. Fel szedé azt az ember, és mondá neki: Soha nem hiszem, hogy te igen gonosz ember ne légy és hitetlen, mert míg tisztelélek és imádálak, semmi jót nem től velem, mastan kegyig, hogy jól meg bintetélek, minden jóval szeretél.

Értelme.

Embernek, gonosznak, mindennek szokása, Hogyha mikoron leszen jó adakozása,

Erével kell hogy legyen annak meg hozása" (146. fabula). ${ }^{4}$

Itt tehát egy házi „fa képről” van szó, amelyet egy ember istenként „imád”, és könyörög hozzá. Tehát ez a fakép nem kapufa, nem kapubálvány, hanem csak egy egyszerü kép (véleményem szerint szentkép), amelyhez imádkoznak.

O. Nagy Gábor (1979: 153) következő (nem dokumentált) forrása egy 18. század közepéről származó marosvásárhelyi per, amelyben a tanú azt vallotta, hogy egy boszorkánysággal vádolt nőszemély megbabonázta a gyermekét,

(5) „s az úgy elszáradott, hogy csak olyan, mint egy fakép”.

Itt a fakép szóláshasonlat formájában bukkan fel, a jelentése pedig az, hogy (a rontás következményeként) a gyermek arca egy valószínüleg rosszul megfestett, nem élethü képhez (festményhez) lett hasonlatos. Ebben az idézetben is a fakép voltaképpen: festmény, és nincs szó bálványról, kapuról.

A faképnél hagy szólásnak több változatát gyüjtötte össze Margalits Ede (1896: 201) az elmúlt kétszáz évböl:

(6) Faképtől vesz búcsút. (Köszönés, búcsúzás nélkül távozik.) E. = Erdélyi János, 1851.

(7) Ott ácsorog a faképnél. D. = Dugonics András, 1820.

(8) Ott hagyták a faképnél. (Szó nélkül ott hagyták.) KV. = Kis-Vicay, 1713. ${ }^{5}$

${ }^{4}$ https://mek.oszk.hu/00600/00660/00660.htm.

5 https://www.arcanum.hu/hu/online-kiadvanyok/Szolasok-regi-magyar-szolasok-eskozmondasok-1/dr-margalits-ede-magyar-kozmondasok-es-kozmondasszeru-szolasok5222. 
Csefkó Gyula (1930: 114) szólásmagyarázatában idézi Faludi Ferenc az Útravaló címü tréfás versét is a nem szívesen látott vendégről (ezt a forrást is átveszik a későbbi szólásmagyarázók):

Ne maraszszuk, el mehet,

A' mint tetszik, úgy vehet

A fa képtöl vég bútsút ${ }^{6}$

Elötte az ország út!

Tehát egy búcsúzó ember, aki előtt az országút, a faképtől vesz búcsút. Ballagi Mórnál (1868: 346) is ugyanilyen konkrét jelentésben szerepel:

(9) Fa-kép: fából faragott kép, szobor, (szójárás) otthagyni valakit a faképnél, szó nélkül.

Az Erdélyi József (1851: 126) közmondásgyűjtésében talált adatban helyzetleírást is találunk:

(10) „Ott hagyták a fa képnél. KV.7 Talán azon magános kereszteknél, melyek a faluk határain, mesgyéjén vannak felállítva a sikon. Faképnél azaz egyedül, mikor az emberhez senki se szólhat."»

Erdélyi nemcsak szólásgyüjtő, hanem jó megfigyelö is egyben. A „fa kép” leírása tökéletes és mindannyiunk számára ismert: a fakép nála a határban található magányos kereszt (korpusz). És teljesen egyértelmü, hogy a határban, az útkereszteződéseknél szoktak az emberek elválni, búcsúzni. Néha fájdalmas, nehéz szívvel, talán örökre. Egy fájdalmas elválás nagyon gyakran szótlan. Esetleg azért, mert a kísérők már elmaradtak. Erdélyi magyarázatában is megjelenik: az egyedül hagyott ember senkihez se szólhat (mert hogy a határban van). Egy ilyen kínzó pszichikai élmény mélyen beleég az ember tudatába, és ezért született meg a szólás: faképnél hagy és faképtől vesz búcsút (köszönés nélkül távozik).

Ezekben az alapvető forrásokban a fakép festett képet (festményt) jelent; Erdélyi konkrétabban határban álló keresztre utal. Szó sincs kapufáról vagy bálványról. A bálvány szó a Czuczor-Fogarasi (1864: 584) szótárban bukkan fel először:

(11) FAKÉP, (fa-kép) ösz. fn. (összetett főnév) Fából faragott kép, fabálvány, faszobor. Ott hagyták a faképnél. (Km.).

A bálvány alapjelentése egyébként 'oszlop' (ma is létezik tengely jelentése), további jelentése: 'bizonyos alakot mutató állvány; imádás végett tartott emberi vagy állati alakot formázó szobor' (Ballagi 1868: 65). Szinnyei (1893-1901: 93) tájszótárában:

${ }^{6}$ Csefkónál: vég bútsút, $\mathrm{O}$. Nagynál: végbúcsút.

7 Kis-Vicay 1713.

8 2503. szólás: https://mek.oszk.hu/09100/09112/html/0002/8.html. 
'szobor' (tehát nem kép); 'nagy dorong; szárazmalomban a középső (külső) nagy tengely' stb.

Tehát Czuczor-Fogarasinál a fakép címszóban a fából faragott kép és faszobor mellett felbukkan a fabálvány szó is. Csakúgy, mint a következő címszóban:

(12) FAKÉPIMÁDÁS, (fa-kép-imádás) ösz. fn. Fából faragott istenek, bálványok imádása.

A faképimádás kapcsán is megfigyelhető a Czuczor-Fogarasi-szótár költőien „kiterjesztő" és sok tekintetben misztikumba hajló (részemről kicsit sem kárhoztatott!) koncepciója. A Czuczor-Fogarasi gyakran engedi szabadjára fantáziáját, távoli kapcsolatokat keres. Így kerülhetett bele a fakép és a faképimádás címszóba a fabálvány, a fából faragott istenek (bálványok) imádása - konkrét adat nélkül. Ezt követően azonban szólásmagyarázóink szabadjára engedték fantáziájukat - ha a CzuczorFogarasinak lehet, miért ne lehetne nekünk is -, és az így eleresztett fantáziából született tetszetős magyarázatot kritika nélkül többen átvették, bekerült a tankönyvekbe, és természetesen ez terjed korlátlanul a világhálón is.

De ki volt az első, aki a faképből kapubálványt csinált? Nyomozásom szerint Csefkó Gyula (1930). Kertész Manó (1931: 13) ismertetésében meg is dicséri: „,a faképnél hagy »fakép«-éről pedig úgy vélekedik, hogy ez emberformára faragott kapufélfa”. De lássuk az eredeti forrást, azaz Csefkó Gyulát (1930: 116):

„Egyes vidékek népies építkezését ismertető dolgozatok többször megemlítik az emberi alakot feltüntető kapufélfát vagy kapubálványt. Viszont más vidékek kapufáinak ma már geometriai díszítményei tagoltságukkal árulják el, hogy a hajdani emberalakú díszítésből stilizálódtak mai formájukba: nem emberalakúak többé, de még most is van fejük, nyakuk és válluk. Hogy az emberszabású kapufélfák régente sokkal gyakoribbak voltak, mint ma, az kétségtelen. Nagyon valószínü, hogy őseink pogány hitvilágának a maradványai és eredetileg a lakóhelyet meg a háznépet védő szellemeket ábrázolták [...]. Hogy ez a föltevés helyes-e vagy téves, annak eldöntése az ethnogprahus dolga. Itt a kérdéshez csak annyit jegyzek meg, hogy egy Reguly-följegyezte osztják hősének is megemlíti a város kapuját őrző horgas karmú, mohos arcú, penészes arcú két jeli-it: a kapu két félfájára kifaragott és a kapu őrzésére hivatott torzalakú, szakállas bálványt $[\ldots]$ Nem lehetetlen, hogy az ajtófélfának a Dráva mellékén járatos örfa [...] neve szintén a kapubálványok hajdani ôrző, védő szerepére utal. De az egészen bizonyos, hogy a kapubálvány-on, meg a szólásainkban emlegetett fakép-en ilyen emberformára faragott kapufélfát kell értenünk.”

És éppen ez az azonosítás az, amit fenntartás nélkül nem tudunk elfogadni. Logikai alapon semmiképpen sem.

Úgy tünik, hogy ettől kezdve nincs megállás: a fakép kapufaként, kapubálványként szerepel. Elhitte Csefkó agyszüleményét Papp István (é. n. 43): „Faképnél hagy valakit, ez a szólásunk például a régi pogány hitvilág maradványa, amikor a kapufa a házat és háznépet védő szellemet ábrázolta”. Így szerepel O. Nagy Gábor (1979: 153) szólásmagyarázatai között is - ő „nyilvánvalónak” (!) tartja, hogy a fakép nem (akármilyen) faszobor, sőt még csak nem is fabálvány, hanem: „amitől hajdan, 
a házból kijövet el szoktak búcsúzni”. Mi azonban mi nem ismerünk ilyen „,búcsúfát”, azt azonban kétségkívül elismerhetjük, hogy létezett ilyen, O. Nagy Gábor által emlegetett szokás: „Egy hódmezővásárhelyi tanár ismerösöm szerint náluk még manapság is szokás, hogy messzire távozó, pl. katonának bevonuló emberek megsimítják - a kapufélfát.” Pontos forrás nélkül utal egy másik, ugyancsak elképzelhető szokásra is, ez azonban nincs kapcsolatban a faképnél hagy szólásunkkal - hanem csak egyik történeti változatával:

„Arra pedig Gömör megyéből van adat, hogy temetéskor, amikor viszik ki a házból a koporsót, néhány percre leteszik a kapu fájára (?), mondván: most búcsúszik a halott a kapufélfától. Az a szólás egyébként, hogy a kapufélfától vagy kapubálványtól vesz búcsút (a. m. 'búcsú nélkül - eredeti értelmében: csak a kapufélfától elbúcsúzva - távozik'), mint a régi nyelvben, mind a mai nyelvjárásokban gyakori."

A faképnél hagy-ról az otthagyta a kapufélfánál-ra való meglehetősen nagy logikai és nyelvi ugrást O. Nagy (1979: 154) így magyarázza: „Mindezek... eléggé meggyőznek bennünket arról, hogy a címül írt szólásunkban a fakép nem akármilyen fabálványt, hanem a szó szükebb értelmében kapubálványt, kapufélfát jelent." Engem azonban ez nem győz meg. Akkor sem, ha további magyarázattal él:

„Természetesen nem a mai, gyakran teljesen sima, dísztelen kapufélfákra kell gondolnunk, hanem az olyan kapubálványokra, amelyek valami emberforma alakot ábrázoltak. Elvétve még ma is találni olyan kapufélfát, melynek felső részén emberi fej van kifaragva, ennél azonban sokkal gyakoribbak az olyan kapubálványformák, amelyek nem ember alakúak ugyan, de hajdani emberalakból stilizálódtak mai formájukra, és még felismerhetők rajtuk a fej, nyak és váll formái. Az ilyen kapufák ősét joggal nevezték (kapu)-bálványnak vagy faképnek, hiszen néprajztudósaink indokolt feltevése szerint ezek a kapubálványok hajdan a házat és a háznépet ôrző szellemeket ábrázolták, tehát a szó szoros értelmében vett bálványok voltak” (O. Nagy 1979: 154).

Elöttünk van tehát a faképnél hagy szólás és ennek egyik történeti változata: faképtöl vesz búcsút. Valamint létezik egy olyan (szerintem másik) szólásunk, hogy kapufélfától (kapubálványtól) vesz búcsút. És esetleg olyan is: otthagyta a kapufélfánál. A faképtöl vesz búcsút és a kapufélfától vesz búcsút keveredése elképzelhetö. A faképnél hagy és az otthagyta a kapufélfánál nyelvi kapcsolata szintaktikai különbözősége folytán már jóval kevésbé hihető. De ha mégis, akkor is pusztán nyelvi kapcsolatról van szó, és ez nem jelentheti azt, hogy a fakép az kapubálvány.

Érdemes visszatérni az eredeti forrásokhoz és magyarázatokhoz: a fakép fából készült (festett) kép (a határban). A legkorábbi adatok ugyanis csak erre utaltak. Álláspontomat megerősíti, hogy az eredeti, 15. századtól adatolható faképjelenség mindmáig él, és erre nem hivatkoznak a szólásmagyarázók. Az országot járva sok helyen találkozhatunk faképekkel vagy (mai kifejezéssel megfordított szószerkezetben) képesfákkal, amelyeket szentfáknak vagy Mária-fáknak is neveznek. A fakép kifejezés ma nem használatos. A képesfa (szentfa) egy tekintélyes (idős) fára (famatuzsálemre) helyezett szentkép; esetleg a fa odvába helyezett kép vagy szobor. 
A legtöbb képesfát gondozzák, mindig van rajta, alatta, körülötte újabb és újabb szentkép, virágcsokor, mécses. Az ország minden részén találhatunk képesfákat. Ezek a képesfák egyfajta spontán, naiv zarándokhellyé, a helyi hitélet fontos elemévé váltak.

Ez a szokás a népi vallásosság körébe sorolható, és mai megjelenésében nálunk keresztény, föleg katolikus hagyomány, de ismert ortodox területen is. Sőt a hinduk és buddhisták is hasonló módon tisztelik a szentfákat. Tehát minden valószínüség szerint ez a szokás is visszavezethető a kereszténység elötti hagyományokhoz. A képes fa ugyanis egyesíti a vallási és a természeti értékek tiszteletét. Egy olyan világkép nyilvánul meg benne, amelyben a természet és az ember még szoros harmóniában élt. Megkapó képi megfogalmazását adja Elen Klimov Búcsúzás (másik címe: Búcsúzás Matyurától, szovjet film, 1981) címú alkotása, amely egy szibériai, elárasztásra ítélt falu végnapjait mutatja be. A falut kiürítik, az értékeket elszállítják. A szentfát azonban nem tudják kivágni, ledózerolni, sőt felgyújtani sem. A szentfa a közösség hagyományokon alapuló összetartozását szimbolizálja.

A magyarországi képesfákra (faképekre) csak nemrég irányult figyelem. Például a Dél-balatoni Természetvédelmi Egyesület honlapon gyüjti a képesfákat. Eddig ezeket dokumentálták: Somogy megye: Libickozma, Kapoly, Somogyvár, Ságvár, Zala megye: Lentiszombathely, Veszprém megye: Tüskevár, Pest megye: Kóspallag, Márianosztra, Telki, Budakeszi, Isaszeg (a péceli útnál található fa elpusztult, de helyét megjelölték), Fejér megye: Gánt. A Mátraháza-Recsk közötti útvonalon három képesfa található. ${ }^{9}$ Gyakran megállok Somogyban a kapolyi képesfánál (mellé egy kopjafát is állítottak). A Pilis hegységben, nem messze a pilisszentkereszti kolostorromoktól a Hármasforrás-völgy és Vaskapu-völgy találkozásánál is található képesfa. Dömösön a Rám-szakadék felé gyalogolva a Malompatak-völgyében húzódik meg a Szentfa kápolna. Ennek történeti emlékét főleg Dömös lakossága és a turisták tartják fenn. ${ }^{10}$

9 Forrás: https://dbte.webnode.hu/magyarorszagi-kepesfak/.

${ }^{10}$ „A Szentfa-kápolna története. A hagyomány szerint 1885-ben, május első vasárnapján két dömösi kisleány libákat legeltetett a falu mögötti mezőkön. Miután egy szép bükkfa alatt letelepedtek, az ég csodálatos kékre váltott, és felnéztükben Szüz Mária képét pillantották meg a fán a kis Jézussal. Mindkét alakon a Szent Korona és a fejük körül glória látszott. Egy arra járó nagyobb gyermek gyorsan a faluba szaladt. A Dömösről hamar megérkező idősebb asszonyok szintén látták a képet. A csodafa búcsújáró hellyé vált. Általában szombaton, este 9-10 óra tájban, teliholdkor volt látható a jelenés. Sokan láttak csillag glóriát a két alak feje körül, mások csak a csillagglóriát, megint mások csak csillagokat láttak. A kápolna a csodafa emlékét őrzi a kis tisztás mellett.

A Szentfaként tisztelt bükkfát Nedeczky Gáspár, Dömösön szolgáló plébános állítólagos sugalmazása nyomán, 1887. április 23-án este, Szabó Mihály alszolgabíró hat csendőrrel kivágatta és a további zarándoklatokat betiltották. A hely tisztelete ennek ellenére sosem szünt meg. A hívek később kis kápolnát építettek a fa mellett. Minden év augusztus 15én, vagy az ahhoz legközelebbi vasárnapon Nagyboldogasszony ünnepnapjára emlékezve, a helyi katolikus lelkipásztor szentmisét mutat be az egyházi föhatóság engedélyével, amelyen a község és környéke hívői buzgón részt vesznek. A kápolna a csodafa emlékét őrzi a kis tisztás mellett, valamint a kápolna mellett erdei turistapihenő is található." Forrás: https://domosinfo.hu/szentfa-kapolna-domos/. 
A faképnél hagy... szólásunk (félre)magyarázói tehát minden bizonnyal kapufát lőttek - méghozzá sorozatosat, hiszen a Csefkó Gyulától eredeztethető tévmagyarázatot kritika nélkül átvették, $\mathrm{O}$. Nagy Gábor pedig még tovább is kerekítette a történetet. Mivel ezeket a közismert forrásokat használja mindenki, az interneten való magyarázatok is mind tévesek. Néha érdemes az első forrásokig visszamenni, a misztikus magyarázatokat kritikusan végiggondolni és bevonni mindennapi tapasztalatainkat. Ez esetben azt, hogy ma is él egy szép népi vallásos hagyomány, a határban, utak mentén, esetleg búcsújáróhelyek közelében álló képesfa, amely sokkal szorosabb kapcsolatba hozható a faképnél hagy szólással, mint a kapufélfa vagy kapubálvány.

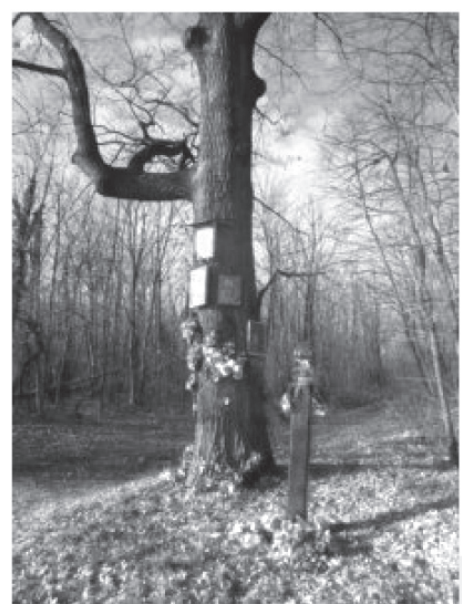

1. kép. A kapolyi képesfa

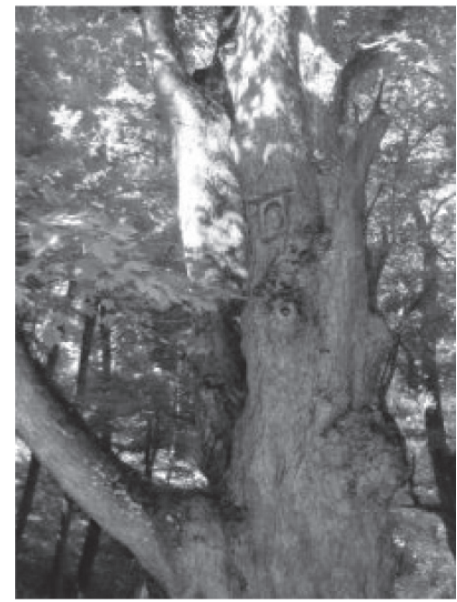

2. kép. A pilisszentkereszti képesfa

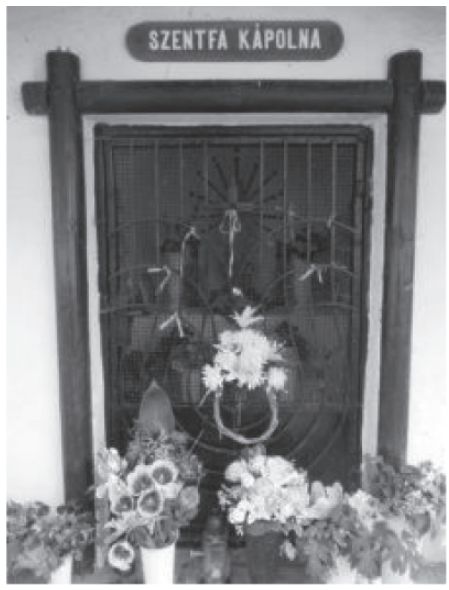

3. kép. A dömösi Szentfa kápolna 
A faképnél hagy szólásmagyarázatot a következőképpen módosítanám a szótárakban.

Faképnél hagy. Jelentése: váratlanul (köszönés nélkül) távozik, otthagy. A fakép összetett szó önállóan nem használatos. Egyedül ebben a szólásban maradt fenn. Föltehetőleg a települések határában, útelágazásoknál, esetleg búcsújáró helyeken álló fakeresztekre utal, hiszen ezeken fordulnak elő faragott-festett (szent)képek, korpuszok. Az útelágazások a búcsúzás tipikus helyei. A szólás a váratlan, fájdalmas, szótlan (hosszú időre, esetleg örökre) szóló elválásra utalhatott; mai jelentése kiterjedt: a felelőtlen, meggondolatlan, indulatból való távozásra is használják. A népi vallásosság megnyilvánulásaként (különösen Dunántúlon) ma is találhatók a határban ilyen faképek (ám ezeket fordított szószerkezettel képes fáknak nevezik), illetve létezik szentfa, Mária-fa megnevezésük is. A faképet a Czuczor-Fogarasi-szótár fából faragott képnek, faszobornak és fabálványnak határozza meg. A fabálvány meghatározást Csefkó Gyula kiterjesztőleg összekapcsolta a kapubálvány jelenségével. Ennek nyomán terjedhetett el számos szólásmagyarázó szótárunkban majd pedig az oktatásban az a téves magyarázat, hogy a szólás a házaknál lévő, talán a házat és háznépet őrző szellemet megjelenítő kapubálványtól vagy kapufélfától való elbúcsúzásra vonatkozik. Csakhogy ez egy másik szólás: búcsút vesz a kapufától (vagy kapubálványtól), amely logikailag, de nyelvileg sem kapcsolható össze a faképnél hagy szólással.

\title{
SZAKIRODALOM
}

Ballagi Mór 1868. A magyar nyelv teljes szótára. Heckenast Gusztáv, Pest. (Reprint: Nap Kiadó, 1998, 2010.)

Bárdosi Vilmos 2003. Magyar szólástár. Tinta Könyvkiadó, Budapest.

Bárdosi Vilmos 2015. Szólások, közmondások eredete. Frazeológiai etimológiai szótár. Tinta Könyvkiadó, Budapest.

Czuczor Gergely - Fogarasi János 1864. A magyar nyelv szótára. Emich Gusztáv magyar akadémiai nyomdásznál, Pest

Csefkó Gyula 1930. Faképnél hagy. In: Szállóigék, szólásmódok. Tanulmányok szóláskészletünk köréből. (A Magyar Nyelvtudományi Társaság kiadványai 28.) Budapest, 113-7.

Kertész Manó 1931. Szállóigék és szólásmódok. Magyar Nyelvőr 60: 11-3.

Margalits Ede 1896. Magyar közmondások és közmondásszerü szólások. Kókai Lajos, Budapest. (Reprint: Akadémiai Kiadó, 1990.)

O. Nagy Gábor 1979. Mi fán terem? Magyar szólásmondások eredete. Harmadik, bővített kiadás. Gondolat Kiadó, Budapest.

Papp István é. n. A magyar nyelvtan nevelöereje. Királyi Magyar Egyetemi Nyomda, Budapest. (A tanítás problémái 3. szám, szerkeszti: Vajthó László.)

Szemerkényi Ágnes 2009. Szólások és közmondások. Osiris, Budapest.

Szinnyei József 1893-1901. Magyar tájszótár. Hornyánszky Viktor kiadása, Budapest. (Reprint: Nap Kiadó, 2003.)

\author{
Balázs Géza \\ egyetemi tanár
}

ELTE BTK Mai Magyar Nyelvi Tanszék, Budapest

Partiumi Keresztény Egyetem, Nagyvárad

https://orcid.org/0000-0003-3440-2959 